\title{
Life Skill Education Development Through Project-Based Learning in Distance Learning at MI Al-Falah UM
}

\author{
Tutuk Ningsih, IAIN Purwokerto, Indonesia, tutuk@iainpurwokerto.ac.id \\ Heru Kurniawan, IAIN Purwokerto,Indonesia, heru_1982@yahoo.com \\ Sri Rahayu, MI Al-Falah UM, Indonesia, cararici@gmail.com
}

\begin{abstract}
The Covid-19 pandemic requires student and teacher to do distance learning/online learning to prevent the formation of new cluster of the spread of the Corona virus. Without face-to-face learning, teacher's role as a facilitator will be minimal. Therefore, teacher must be able to design an appropriate learning activity model to make effective and efficient learning. So that the objective of learning can be achieved optimally. One of them is by focusing home learning activity on life skill education regarding the Covid-19 pandemic through Project-Based Learning (PjBL). Project-Based Learning (PjBL) focuses on encouraging student to create interesting learning experience by thinking creatively and working together to create real project to solve problem faced through: (1) personal skill, equip the student in identifying various problems faced during the Covid-19 pandemic through various information; (2) academic skill, equip the student to make academic procedure to solve problem during the Covid-19 pandemic; (3) social skill, enable the student to communicate problem with social environment so that they can find a formula for solving their environment problem; (4) vocational skill, make skilled student in solving problem with the product that they created. This is where Project-Based Learning (PjBL) developed by MI Al-Falah UM during the Covid-19 pandemic is able to improve students' life skills during distance learning.
\end{abstract}

Keywords: distance learning, life skill education, project-based learning.

Received: 05.12.2020 $\quad$ Accepted: 24.01.2021 $\quad$ Published: 03.02.2021

\section{INTRODUCTION}

School is formal educational institution to educate and develop children's abilities that have been provided by God since their birth. Through education in school, the children are expected be able to adapt to change in global environment with development of science and technology that occur. National Education System Law No. 20 of 2003 section 3 states that national education aims to develop the potential of student to become human being who believe and fear God Almighty, have noble character, healthy, knowledgeable, capable, creative, independent, and become democratic and responsible citizen (Marwiyah, 2020, p. 87). Based on the juridical foundation, education is needed to fulfill the objective of education. Life skills education is an effort to prepare student to have attitude and life skill as provision for their future life through active, creative, and fun learning activity (Mislaini, 2017, p. 149).

The development of life skill is based on the philosophy of education which is defined as the process of acquiring useful learning experience for the student, the experience is expected to be able to develop the potential of student, so they could solve problem of their live (Mislaini, 2017, pp. 155-156). Shaumi states that life skills are the skills to adapt to positive behavior that allow individual to react effectively in facing daily need and challenge (Shaumi, 2015, p. 242). Life skill education has become a policy in line with the enactment of content standard and graduate competency standard which is used as reference in developing curriculum in each educational unit. Therefore, the teacher should have an active role in providing direction as material to be formulated and processed by student in learning process. As much as possible, educator must strive for the relevance of education to real-life value, thus encouraging student to learn contextually and realistically.

Then the problem is how the education in school can develop students' life skill when the education use distance learning during the Covid-19 pandemic? We also know, since the Covid-19 pandemic, the Minister of Education and Culture, Nadiem Makarim decided that school in yellow, orange, and red zone should not conduct face-to-face learning to prevent the formation of new cluster of the spread of the Corona virus. The learning process is also carried out online or known as the distance learning process. Since March 4, 2020, UNESCO (United Nation Educational Scientific and Cultural Organization) has also suggested the use of distance learning by opening an educational platform that school and teacher can use to reach student remotely and overcome educational disruption (Setiawan, 
2020, p. 29). According to Munir distance learning is when there is no contact directly between teacher and student in learning process, the process learning is using media such as computer, television, radio, internet, video, and so on as two-way communication tool (Munir, 2009, p. 17).

Wekke \& Hamid states the information technology can be accepted as medium in carrying out the educational process, including helping the teaching and learning process, which also involves finding reference and source of information (Khusniyah \& Hakim, 2019, p. 20). Without direct face-to-face contact between teacher and student, the teacher's role as a facilitator will be minimal. Therefore, the teacher must design a learning model that is able to teach knowledge, skill, and attitude by utilizing technology, so that educational goals can be achieved even without face-to-face contact. Based on circular issued by Minister of Education and Culture of the Republic of Indonesia No.4 of 2020 concerning Implementation of Education Policies in Emergency for the Spread of Covid, it was explained that online/distance learning process is carried out to provide meaningful learning experience for student. Studying at home can focus on life skill education, including regarding the Covid-19 pandemic (Dewi, 2020, p. 56).

The Covid-19 pandemic does not only have an impact on health sector. The existence of a government policy regarding the prohibition of activity that cause crowds has an impact on social, economic, tourism and education sectors. Student and teacher have to face new challenge. According with education policy in emergency period of spread of Covid which focuses on meaningful experience and life skill education, the learning model must be designed and bring positive impact on student to solve problem of their current life. One of the alternative learning model is Project-Based Learning (PjBL). Intel@Teach Program states PjBL is learning model that involves student in investigating urgent problems that end up in authentic product (Karakter Kewirausahaan, Sains, Keterampilan, Wikanta, \& Gayatri, 2010, p. 172). Meanwhile, as stated by Kristanti et al. project-based learning help student design and find solution to solve a problem. Train students to manage information and produce a tangible product (Kristanti, Subiki, \& Handayani, 2016, p. 123). Project-based learning emphasizes studentcentered learning which places student as an active student in psychomotor, affective and cognitive (Adinugraha, 2018, p. 2). Project-based learning according to Muderawan is considered effective and challenging as a tool to teach student actively because student is encouraged to be more independent, not depend entirely on teacher's direction (Jannatu, Imah, Dan, \& Wardani, 2015, p. 156). For this reason, the project-based learning is very appropriate to use in distance learning where teacher and student cannot do face-to-face learning and teachers' role as a facilitator is greatly reduced.

Life skill education through project-based learning in distance learning is carried out using internet as communication tool. The teacher designs guideline for learning activity to make easier for student to complete learning activity. The learning stage begins with student identifying problems faced today. For example, for health problem, most people need a mask or hand sanitizer. Or family economic problem, when income of family is reduced during pandemic. Student is asked to find a solution by making economic value item that is needed by seeking information from various sources. Students are assigned to market the product in person or via internet. All learning activities that have been carried out are reported to the teacher online. This means that teacher and student have implemented life skill education through project-based learning in distance learning.

\section{METHODS}

The research method used is qualitative description that focuses on life skill education through projectbased learning in distance learning in grade $6 \mathrm{MI}$ Al-Falah UM. Raco states, the qualitative research method is an approach to exploring and understanding a central phenomenon where the information obtained is analysed in the form of description (J.R. Raco, 2010, p. 7). Description does not intend to seek the truth of the fact, but to re-describe phenomenon precisely (Subandi, 2011, p. 174). The information or data obtained is collected and identified through three techniques: (1) observation on project-based learning activities for 6 grader MI Al-Falah UM by providing guided assignment, observation via video call with student when they completing project during distance learning; (2) interview with student and those who helped complete the project (parents or other family members) during distance learning; (3) documents for project-based learning activity in the form of photos, videos, and guideline during distance learning.

\section{RESULTS AND DISCUSSION}

The study focuses on exploring and assessing life skill education through project-based learning in grade $6 \mathrm{MI}$ Al-Falah UM. In distance learning, the implementation of activity is under the guidance of parent or family at home and teacher as a facilitator. Life skill education through project-based learning is 
patterned on the following elements: (1) personal skill, students are stimulated to be able to think rationally through identifying real problem and making decision to make project to be worked on. Planning the use of income from the project made; (2) academic skill, student relate scientific information from various source with the phenomena that occur and apply it in project; (3) social skill, activitiy in collaboration with parent, friend or all those who helped to completing project and market activity; (4) vocational skill, student determine the selling price, calculate the income, reflecting on taking step to improve next project.

\section{Personal Skill}

The initial stage of project based-learning during distance learning begins with the provision of project learning guideline via google form by teacher. Student identify most impactful problem surrounding environment due to Covid-19 pandemic. For example, health problem, fulfilment of the increasing need for mask or the soaring need for hand sanitizer but they was rare in the market, or economic problem, decreased income in family, and so on. After identifying a problem, student design a project to produce a product than can solve that problem. Students are trained to think rationally by exploring, finding, and processing information to make decision. They learn to solve problem creatively. Students are also trained to consider the strength and weakness owned as a reference for successful completion of project. These two skills are personal skill (Marwiyah, 2020, p. 86).

Students are divided into five groups. Each group consists of six to eight students according to the area of residence. These group are called Camp 1, Camp2, and so on. Through google form from the teacher, students are stimulated to identify closest problem to them. These questions include; (1) What problem did you encounter during the Covid-19 pandemic? (2) Which problem do you think is easiest to solve? (3) Why is that problem the easiest to solve? (4) What project will you make to solve the problem?

In this activity, one group make hand sanitizer, one group make mask, and other three groups will make food. The reason of Camp 1 make hand sanitizer is because it is quite difficult to find and expensive in their surrounding environment. Hand sanitizer that are made can be used to own or sold. In addition, make hand sanitizer is easy. Camp 2 choose to make food because one of member group had a catering business that was still operating and even demand increased during pandemic and work from home (WFH) activity. Their parents will guide students to complete food project according to order. Camp 3 choose to make snacks, donut and chip. These food are considered easy to sell. The prohibition of activities outside (\#DirumahAja) make people more fond of snacking when gathering at home. Camp 4 chooses to make mask because the parent of member is a tailor. She will teach children and other parents to make mask. They use remaining material of cloth to make mask (patchwork), so it will reduce production cost. They will create beautiful mask at low price to attract buyer because the kind of this mask still rarely found in their surrounding area. Camp 5 make Asinan Betawi (Jakarta specialties), many people like this food. Especially they have different recipe from other Asinan Betawi.

In this stage, students are trained to have personal skill education. Through online learning students are conditioned to able to observe problem experienced by themselves, their family, and their surrounding. By identifying the problem, student will be able to formulate and decide many steps to solve problem through particular project.

\section{Academic Skill}

After the student decide what project to work on, students are required to make report via google form. The report contains the description of reason for selecting project. Why the project is considered capable of solving the problem that occur. They have to give scientific reason by reffering to various reliable sources and related with phenomena. The report also contain procedure for project completion, accompanied by photo and video of project completion process. This stage allows student to develop rational thinking skill, linking scientific information from various sources and the application. Learning activity becomes more meaningful for student by integrating concepts from many components of knowledge or field study. Marwiyah explains that by identifying variables and explaining their relationship to certain phenomenon, it means that student have learned academic skill education (Marwiyah, 2020, p. 87).

The process of completing the Camp 1 project in making hand sanitizer begins by collecting information and tutorial to make hand sanitizer from youtube channel, then choosing the easiest and cheapest procedure. They chose a hand sanitizer made from stew of betel leaf mixed with lime. Betel leaf is easy to find in their environment. The report explains content of betel leaf and lime which used as a basic ingredient. Camp 2 complete project to make food by order in catering business. They work according to instruction of parent under guidance some employees and parent. The report describe nutrition of food that they made and every step to cook the food. The completion of Camp 3 project is 
guided by parents. They start from select the ingredient and the way to make donut and chip. The report describes nutrition of the ingredient and the step to make donut and chip. Camp 4 completes project under the guidance of parents, they choose suitable materials, forming pattern, cutting, sewing, decorating and packaging. The report describes the importance of wearing masks and step to making beautiful mask. The completion project of Camp 5, the parents tell the student about choose good ingredient to make asinan and the way to make asinan. The report describes nutrition of fruits in asinan and step to make it.

Students are asked to filled out some questions in google from, the questions are; (1) Write down the reason for choosing the product? (2) Explain the excellence of your product? (3) Write down the steps for completing your project! (4) Upload videos and photos showing the process of completion product! This stage makes student carry out academic studies through various reference sources, and makes student have a set of academic knowledge. Then the knowledge is used to build argument for each step to solve problem. Student's academic skill will develop because they able to find, identify, connect, and apply scientific information from various sources in solving problem that have been found.

\section{Social Skill}

Nakayama argues that success of online learning is determined by environmental factors. In this case, including guide. In distance learning, students are guided by parent or other family members. Projectbased learning during distance learning allow student to work together in completing project. Cooperative activity train social skills to student through two-way communication, practice the art of communication, build empathy and grow harmonious relationship (Marwiyah, 2020, p. 86). While working together, the students will express their opinion, listen to suggestion, accept criticism, take and give help, reduce ego in order to achieve goal, prioritize common interests, and so on. It is important instill social skill from early age because human is social creature.

Student are required to manage the art of communication with friends or guide during work together to complete a project. Students are asked to fill the questions on google form; (1) Who guide you in completing the project? (2) Write down your opinion about your guide? (3) Mention who worked with you to complete the project! (4) How do you feel about working with them? (5) Did you have any problem during completing the project with them? (6) How do you solve the problem?

This stage is expected to condition the student to build communication with their friends and people around them intensively. In this case, student's understanding of other person is formed. They will realize the importance of other person's role to complete the project. From here, the student can do on going cooperative working for the sake of realizing common interest. This way improves student's social skill to be better individual and social creature in society.

\section{Vocational Skill}

Vocational skill is related to field of work that require motoric skill. It is also related with economic skill and development of employability. In project-based learning, student produces a product (Marwiyah, 2020, p. 87). The product is expected to solve problem of environment around them. Vocational skill is trained through student activity to market product in person or via internet. Students discuss with their guide to determine the selling price by calculating target of income and expense. Then evaluate their project and discuss improvement strategy for the next project.

In this stage, student fill out the questions on google form; (1) Write down the expense required to complete your project? (2) How do you determine the selling price of your product? (3) How much income do you get from selling your product? (4) Count the profit or loss sale that you get! The teacher suggests to donate some of the profit to help other. (5) Explain your plan to get bigger profit in the next sale? The questions make student do a series of direct skill activities in making hand sanitizer, making some food, and mask as the main solution of the problem. The organized manufacturing process make student have vocational skill, the skill in making something to be solution of problem, calculate and evaluate the project activity and product that they are made.

Life skill education through project-based learning in distance learning developed by MI Al- Falah UM can be seen in figure 1 . 


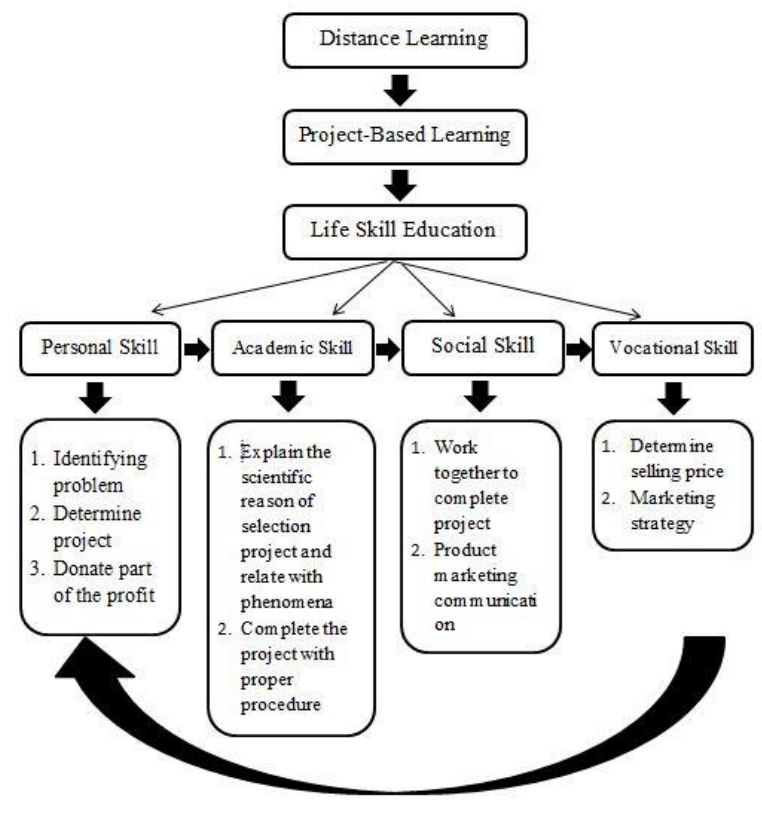

Figure 1. Chart of life skills education through project-based learning in distance learning developed by MI Al-Falah UM

Through project-based learning (PjBL), online learning/distance learning becomes more meaningful and fun. Even though the teacher's role is minimal because there is no face-to-face meeting, and teacher only provides direction through question on the google form, students are still able to get information and knowledge because the characteristic of PjBL is student centered learning, where students are directly involved in solving the problem they face through a series of creative and collaborative processes. Some of the obstacles faced in this learning process including; (1) It takes a long time to complete the learning; (2) It costs money; (3) Difficult to arrange meeting because the learning process is carried out during pandemic period, discussion take virtually; (4) Limited student movement because they have to adapt to strict health protocols such as use masks or face shield; (5) Difficulty in marketing because there are many "impromptu seller" during the pandemic who become competitors. In order to make easier for student and parent, life skill education through project-based learning in grade 6 at MI Al-Falah in distance learning is currently flexible. The time span given is until the end of odd semester (early December 2020) with only one learning cycle (from problem identification up to marketing activity), and profit is not an absolute target in marketing.

\section{CONCLUSIONS}

Based on conceptual analysis and elaboration of the data and information collected, it can be concluded that the project-based learning process of grade 6 in MI Al-Falah UM during online/distance learning has carried out life skill education which includes; (1) personal skill, identifying problem and decide on project to solve problem; (2) academic skill, making report and relating scientific information to phenomena; (3) social skill, the art of communicating in collaboration and maketing; (4) vocational skill, marketing management. Through project-based learning, the distance learning process which was initially saturated and difficult because of lack of guidance from the teacher become more meaningful, the learning process provide student with experience to be independent, think critically and creatively, find solutions to problem solving, collaborate and even benefit themselves and the environment.

\section{REFERENCES}

Adinugraha, F. (2018). Model Pembelajaran Berbasis Proyek Pada Mata Kuliah Media Pembelajaran. SAP (Susunan Artikel Pendidikan), 3(1). https://doi.org/10.30998/sap.v3i1.2728 
Dewi, W. A. F. (2020). Dampak COVID-19 terhadap Implementasi Pembelajaran Daring di Sekolah Dasar. EDUKATIF : JURNAL ILMU PENDIDIKAN, 2(1), 55-61. https://doi.org/10.31004/edukatif.v2i1.89

J.R. Raco. (2010). Metode Penelitian Kualitatif : Jenis, Karakteristik dan Keunggulannya. Jakarta: Grasindo.

Jannatu, N., Imah, N. ', Dan, S., \& Wardani, S. (2015). PENERAPAN PEMBELAJARAN BERBASIS PROYEK BERBANTUAN E-LEARNING UNTUK MENINGKATKAN HASIL BELAJAR SISWA. In Jurnal Inovasi $\begin{array}{lllll}\text { Pendidikan Kimia } & \text { (Vol. } & 9 \text { ). } & \text { Retrieved }\end{array}$ https://journal.unnes.ac.id/nju/index.php/JIPK/article/view/4824

Karakter Kewirausahaan, M., Sains, K. P., Keterampilan, D., Wikanta, W., \& Gayatri, Y. (2010). PEMBELAJARAN BERBASIS PROYEK DALAM BERPIKIR TINGKAT TINGGI MAHASISWA. In Jilid (Vol. 17). https://doi.org/10.17977/JIP.V23I2.10977

Khusniyah, N. L., \& Hakim, L. (2019). EFEKTIVITAS PEMBELAJARAN BERBASIS DARING: SEBUAH BUKTI PADA PEMBELAJARAN BAHASA INGGRIS. Jurnal Tatsqif, 17(1), 19-33. https://doi.org/10.20414/jtq.v17i1.667

Kristanti, Y. D., Subiki, S., \& Handayani, R. D. (2016). MODEL PEMBELAJARAN BERBASIS PROYEK (PROJECT BASED LEARNING MODEL) PADA PEMBELAJARAN FISIKA DISMA | JURNAL PEMBELAJARAN FISIKA. Retrieved December 14, 2020, from https://jurnal.unej.ac.id/index.php/JPF/article/view/3958

Marwiyah, S. (2020). KONSEP PENDIDIKAN BERBASIS KECAKAPAN HIDUP.

Mislaini, M. (2017). PENDIDIKAN DAN BIMBINGAN KECAKAPAN HIDUP (LIFE SKILL) PESERTA DIDIK. Tarbawiyah Jurnal Ilmiah Pendidikan, 1(02), 88. https://doi.org/10.32332/tarbawiyah.v1i02.974

Munir. (2009). Pembelajaran Jarak Jauh Berbasis Teknologi Informasi dan Komunikasi. Bandung: Penerbit Alfabeta.

Setiawan, A. R. (2020). Lembar Kegiatan Literasi Saintifik untuk Pembelajaran Jarak Jauh Topik Penyakit Coronavirus 2019 (COVID-19). EDUKATIF: JURNAL ILMU PENDIDIKAN, 2(1), 28-37. https://doi.org/10.31004/edukatif.v2i1.80

Shaumi, A. N. (2015). Pendidikan Kecakapan Hidup (Life Skill) dalam Pembelajaran Sains SD/MI. TERAMPIL: Jurnal Pendidikan Dan Pembelajaran Dasar, 2(2), 240-252. Retrieved from http://ejournal.radenintan.ac.id/index.php/terampil/article/view/1295

Subandi. (2011). DESKRIPSI KUALITATIF SEBAGAI SATU METODE DALAM PENELITIAN PERTUNJUKAN. Harmonia: Journal of Arts Research and Education, 11(2). https://doi.org/10.15294/harmonia.v11i2.2210 